УДК 347.724.028:35.075

DOI https://doi.org/10.32837/yuv.v0i1.1634

I. Воротинцева,

аспірант кафедри цивільного права

Національного університету «Одеська юридична академія»

\title{
ЩОДО ВИЗНАЧЕННЯ ПОНЯТТЯ ФОП ЯК СУБ'ЄКТА ЦИВІЛЬНОГО ПРАВА
}

Розвиток ринкової економіки зумовив появу нових соціальних зв'язків, що вимагають правового регулювання. Як регулятор цих цивільних зв'язків виступає цивільне право. Отже, цивільні зв'язки $€$ цивільно-правовими відносинами, які, у свою чергу, складаються з елементів - суб'єктів та об'єктів правовідносин. Суб'єктом права $є$ індивід або організація, що володіють закріпленим у законі комплексом прав та обов'язків і здатні вступати у правові відносини.

Найбільш часто використовується розподіл суб'єктів права на фізичних осіб і юридичних осіб [1]. Громадяни (фізичні особи) є природними суб'єктами права, вони виникли й існують незалежно від належності до певних форм політичних товариств. На противагу цій категорії суб'єктів виступають юридичні особи (організаціі), які являють собою штучні суб'єкти й можуть існувати тільки там, де існує право. Це підтверджується також і моментом виникнення цих двох категорій суб'єктів і моментом припинення їхньоі правоздатності. Фізична особа-підприємець, за загальним поняттям, розглядається як дієздатна особа, зареєстрована в установленому порядку і здійснює на свій ризик і під свою майнову відповідальність самостійну професійну господарську діяльність. Однак при цьому в цивільному законодавстві України немає визначення фізичної особи-підприємця як суб'єкта цивільного права, а лише визначено його права, обов'язки та відповідальність. Така саме ситуація склалася й у Господарському кодексі (далі - ГК) України.
Теоретичну основу дослідження становлять наукові праці таких науковців, як B.I. Борисова, I.В. Спасибо-Фатєєва, Р.А. Майданик, Н.С. Кузнєцова, О.В. Дзера, О.Ю. Заіка, Є.О. Харитонов, В.I. Жилінкова, 3.В. Ромовська, Д.Н. Кархалєв, Р.О. Халфіна, Ю.К. Толстой, Г.Ф. Шершеневич та інші.

Метою статті $€$ науковий аналіз загальних положень законодавства України з метою визначення поняття «фізична-особа підприємець» як суб'єкт цивільного права.

3 метою надання визначення поняття «фізична особа-підприємець» як суб'єкт цивільного права варто для початку надати відповідне визначення поняття «підприємницька діяльність» відповідно до цивільного законодавства України. Проаналізувавши цивільне та господарське законодавства України, убачаємо відсутність чіткого визначення таких понять, як «фізична особа-підприємець» i «підприємницька діяльність».

У ГК України надається визначення поняття «підприємництво», яке розглядається як систематична, ініціативна, самостійна господарська діяльність, що здійснюється суб'єктами господарювання на їхній власний ризик з метою досягнення результатів економічного й соціального характеру та отримання прибутку. Таке саме визначення надається в Законі України «Про підприємництво» [2]. У Цивільному кодексі (далі - ЦК) України визначення поняття «підприємництво» відсутнє.

Українські вчені: В.Ф. Опришко, Ф.П. Шульженко, С.І. Шимон - у дослі- 
дженнях розглядають підприємницьку діяльність у порівнянні з господарською діяльністю й визнають схожий зміст указаних понять. Надаючи характерні ознаки підприємницької діяльності, указані науковці подають визначення поняття «підприємництво». У дослідженнях О.Л. Ануфрієвої, Т.Г. Плачевської, Г.М. Лагоцької [3] також розглядається підприємницька діяльність, при цьому науковці подають визначення саме поняття «підприємництво».

На нашу думку, поняття «підприємництво» та «підприємницька діяльність» $€$ синонімами. Так, підприємницька діяльність у нашому розумінні - діяльність суб'єкта цивільних правовідносин у сфері підприємництва 3 метою отримання прибутку від своєї діяльності: підприємництво - діяльність суб'єктів цивільних правовідносин з метою прийняття інноваційних ідей для систематичного отримання прибутку від виробництва, продажу товарів (вироблених або придбаних для подальшого продажу) та надання послуг.

Отже, ураховуючи думку інших учених, можемо погодитися 3 їхньою позицією щодо тотожності понять «підприємництво» та «підприємницька діяльність», так як будь-яка діяльність суб'єктів цивільних правовідносин спрямована на отримання прибутку.

Разом із тим, ураховуючи позицію вчених і керуючись положеннями ст. ст. 50-54, 906 ЦК України [1] і ст. ст. 43-44 ГК України [3], надамо таке визначення поняття «підприємницька діяльність». Так, підприємницька діяльність - це діяльність зареєстрованих у встановленому порядку фізичних і юридичних осіб, які самостійно, ініціативно й систематично здійснюють свою господарсько-підприємницьку діяльність з урахуванням можливих ризиків такої діяльності та особистої майнової відповідальності 3 метою досягнення очікуваного результату, який передбачає отримання прибутку в результаті реалізації на ринку виготовленої, переробленої або придбаної для подальшого продажу продукціі, в результаті вико- ристання майна, а також у результаті виконання послуг.

Отже, з визначення підприємницької діяльності можна виділити п'ять основних складників такої діяльності: 1) це самостійна діяльність (здійснювана за своїм бажанням і у своїх інтересах); 2) це діяльність, здійснювана в цивільному обороті від свого імені, на свій ризик і під свою майнову відповідальність; 3) це діяльність, спрямована на систематичне отримання прибутку; 4) отримання прибутку відбувається від користування майном, продажу речей, вироблених, перероблених або придбаних для продажу, а також від надання послуг; 5) послуги призначені для реалізаціі іншим особам.

За ЦК України, підприємницькою діяльністю має право займатися фізична або юридична особа, при цьому акцентується увага на тому, що фізична особа повинна мати повну цивільну дієздатність і бути зареєстрованою з відповідним статусом. Однак не варто забувати, що фізична особа-підприємець - це передусім фізична особа, яка є природним суб'єктом цивільного права. Звідси, відповідно до ЦК України, для виступу в підприємницькій діяльності в статусі фізичної особи-підприємця особа повинна бути дієздатною, бути легітимізованою в результаті іï державної реєстрації як фізичної особи-підприємця без статусу юридичної особи.

У сучасній літературі під час визначення поняття «індивідуальний підприємець» указується, що для його розкриття необхідно усвідомити сутність поняття «суб'єкт цивільного права».

Під суб'єктом цивільного права прийнято розуміти учасника цивільних правовідносин, наділеного певними правами й обов'язками. Суб'єкти цивільного права наділяються певними юридичними властивостями, серед яких прийнято виділяти такі властивості, як правоздатність і дієздатність.

Юридична наука виробила критерії визначення суб'єктів права, до яких, належать, по-перше, ознаки відокремленості особи від інших, їі авто- 
номність, по-друге, індивідуалізація, по-третє, волездатність, по-четверте, прояв особи себе зовні як учасника правовідносин, правової комунікації, що передбачає визнання особи стороною правовідносин, по-п'яте, передбачається ставлення до особи як найважливішої соціально-правової цінності.

3 огляду на зазначене вище, розгляд питання про фізичну особу-підприємця як суб'єкта цивільного права варто почати з визначення цього поняття.

Уважається, що до жодної з категорій цивільних правовідносин фізична особа-підприємець повністю зарахованою не може бути. Право звернення до реєструючого органу може розглядатися як елемент загальної правоздатності фізичних осіб. Цим правом володіє вже виключно фізична особа-підприємець, але як громадянин він не перестає бути фізичною особою й не втрачає своєї правосуб'єктності.

Фізична особа-підприємець визначається як суб'єкт підприємництва. Вивчення суб'єкта підприємницької діяльності передбачає попереднє пізнання статусу суб'єкта цивільного права, правовий режим якого повністю поширюється й на суб’єкта підприємницької діяльності. Іншими словами, перш ніж стати суб'єктом підприємницької діяльності, особа є суб'єктом цивільного права.

Окремі українські вчені під суб'єктом підприємницької діяльності, яким $€$ фізична особа-підприємець, розуміють такий суб'єкт цивільного права, який на свій ризик здійснює самостійну діяльність, спрямовану на систематичне отримання прибутку від користування майном, продажу товару, виконання робіт або надання послуг, i який зареєстрований у цій якості в установленому законом порядку [3].

За відправну точку, з якої починається діяльність фізичної особи-підприємця, прийнято вважати момент державної реєстрації як фізичної особи-підприємця.

Процедура державної реєстрації фізичної особи-підприємця як суб'єкта підприємницької діяльності, який передусім є суб'єктом цивільного права, має конструктивне значення.

Під час державної реєстрації фізичної особи-підприємця заявником може бути тільки фізична особа, яка звертається за державною реєстрацією або зареєстрована як фізична особа-підприємець. Іншими словами, громадянин не має права уповноважити іншу особу надати від свого імені до органу державної реєстрації необхідні для державної реєстрації документи. Правоздатність фізичної особи-підприємця починається з моменту державної реєстрації фізичної особи в цій якості.

Якщо розглядати можливість займатися підприємницькою діяльністю лише як істотне доповнення цивільної правосуб'єктності особи, то варто зазначити, що вплив цієї можливості на цивільну правосуб'єктність фізичної особи настільки великий, що змушує переглянути деякі, здавалося б, непорушні правила. Утрачаються настільки звичні Й стабільні орієнтири у визначенні правового становища особи, іiі юридичних можливостей. Наприклад, починає набувати сенс твердження, що дієздатність громадянина не виникає в повному обсязі з моменту повноліття, тобто настання вісімнадцятирічного віку. Дійсно, якщо вважати, що право займатися підприємницькою діяльністю - елемент загальної правоздатності фізичної особи, то, відповідно, своїми діями придбати це право особа має з моменту виникнення дієздатності в повному обсязі. Однак закон установлює, що право займатися підприємницькою діяльністю особа набуває не з моменту настання повноліття, а 3 моменту державної реєстрації як фізичної особи-підприємця.

Отже, якщо прийняти можливість займатися підприємницькою діяльністю за елемент загальної правоздатності особи, то повна дієздатність не настає 3 моменту повноліття. Більше того, у такому разі повна дієздатність може не виникнути взагалі, якщо особа не проявить бажання займатися підпри- 
ємницькою діяльністю як фізична особа-підприємець.

Зайняття підприємницькою діяльністю передбачає можливості особи бути власником, укладати договори, створювати юридичні особи, бути суб'єктом виключних прав на результати інтелектуальної діяльності тощо. Це право за своєю структурою цілком можна порівняти з правоздатністю загалом.

Правоздатність фізичної особи-підприємця пов'язується з моментом державної реєстрації фізичної особи в цій якості, що дає змогу ставити питання про зарахування іï до категорії штучних суб'єктів громадянського права, якими $є$ юридичні особи. Однак не варто забувати, що фізична особа-підприємець це передусім фізична особа, яка є природним суб'єктом цивільного права.

Отже, до жодної із цих категорій індивідуальний підприємець повністю зарахований не може бути. Постає питання про виділення його як окремого суб'єкта цивільного права. У літературі існує думка, що це не можливо й не доцільно, з огляду на те що право займатися підприємницькою діяльністю входить у загальну правоздатність фізичної особи.

Однак ми дотримуємося іншої позиціï, стверджуючи, що 3 виникненням повної дієздатності як здатності набувати права і створювати обов'язки правоздатність і дієздатність фізичної особи-підприємця не виникають. Їх виникнення законодавець пов'язує з додатковими діями. На наш погляд, саме право звернення до органу реєстрації може розглядатися як елемент загальної правоздатності фізичних осіб, а не саме право здійснення підприємницької діяльності.

Цим правом володіє вже виключно фізична особа-підприємець, воно, на нашу думку, становить зміст іiі правоздатності. Безумовно, зареєструвавшись як фізична особа-підприємець, громадянин не перестає бути фізичною особою й не втрачає своєї правосуб'єктності. При цьому в окремих правовідносинах він виступає як самостійний суб'єкт, що володіє іншим правовим статусом. Тут ми стикаємося з тим, що, по суті, в одній особі поєднуються два різні правові статуси. Це свого роду фікція, коли одна особа $є$, по суті, двома різними суб'єктами громадянського права.

Разом із тим пропонуємо визначення поняття «фізична особа-підприємець». Так, фізична особа-підприємець - це дієздатна фізична особа, зареєстрована в установленому порядку в статусі фізичної особи-підприємця без статусу юридичної особи, яка здійснює на свій ризик і під свою майнову відповідальність самостійну, професійну, підприємницьку діяльність з метою отримання прибутку від такої діяльності, має певні права й обов'язки, обумовлені підприємницькою діяльністю.

У статmі визначається, що розвиток ринкової економіки зумовив появу нових соціальних зв'язків, які вимагають правового регулювання. Як регулятор цих цивільних зв'язків виступає циивільне право. Отже, цивільні зв'язки є иивільно-правовими відносинами, які, у свою чергу, складаються з елементів - суб'єктів та об'єктів правовідносин. Суб'єктом права є індивід або організація, що володіють закріпленим у законі комплексом прав та обов'язків $і$ здатні вступати у правові відносини.

Найбільи часто використовуеться розподіл суб’єктів права на фізичних осіб і юридичних осіб. Громадяни (фізичні особи) є природними суб'єктами права, вони виникли й існують незалежно від належності до певних форм політичних товариств. На противагу ичій категорії суб’єктів виступають юридичні особи (організаціï), які являють собою штучні суб'єкти й можуть існувати тільки там, де існуе право. Це підтверджується також $і$ моментом виникнення циих двох категорій суб'єктів, і моментом припинення їхньӧ правоздатності. Фізична особа-підприємець визначається як суб'єкт підприємництва. Вивчення суб'єкта піоприємниць- 
кої діяльності передбачає попереднє пізнання статусу суб'єкта циивільного права, правовий режим якого повністю поширюеться й на суб'єкта підприємницької діяльності. Іншими словами, перш ніж стати суб'єктом підприємницької діяльності, особа $є$ суб'єктом изивільного права.

Пропонуеться таке визначення поняття: фізична особа-підприємець - ие дієздатна фізична особа, зареєстрована в установленому порядку в статусі фізичної особи-підприємия без статусу юридичної особи, яка здійснюе на свій ризик $i$ піо свою майнову відповідальність самостійну, професійну, підприємницььку діяльність з метою отримання прибутку від такої діяльності, має певні права й обов'язки, обумовлені підприємницькою діяльністю.

Ключові слова: цивільні правовідносини, організаційні правовідносини, фізична особа-підприємець, суб'єкти цивільного права.

Vorotyntseva I. On the definition of the individual entrepreneur as a subject of civil law

The article states that the development of a market economy has led to the emergence of new social bonds that require legal regulation. Civil law acts as a regulator of these civil relations. Thus, civil relations are civil-law relations, which in turn consist of elements-subjects and objects of legal relations. The subject of the law is an individual or organization, possessing a set of rights and obligations enshrined in the law and capable of entering into legal relations.

The most commonly used is the distribution of legal entities for individuals and legal entities. Citizens (individuals) are natural subjects of law, they arose and exist regardless of belonging to certain forms of political societies. In contrast to this category of entities are legal entities (organizations) that are artificial entities and can only exist where there is a right. This is also confirmed by the moment of emergence of these two categories of subjects and the moment of termination of their legal capacity. An entrepreneur is defined as a business entity. The study of a business entity involves prior knowledge of the status of a civil law entity, the legal regime of which fully extends to the business entity. In other words, before becoming a business entity, a person is a subject of civil law.

The following definition of the term "natural person entrepreneur" is proposed - is a capable natural person, registered in the established order in the status of a natural personentrepreneur without the status of a legal entity, which carries out at his own risk and responsibility under his own responsibility independent, professional, business activity, in order to obtain profit from such activities, has certain rights and obligations, due to entrepreneurial activity.

Key words: civil relations, organizational legal relations, entrepreneur, civil law subjects.

\section{Література}

1. Цивільний кодекс України : Закон України від 16.01.2003 № 40-44. URL: https: / / zakon.rada.gov.ua/laws / show/ 435-15

2. Про підприємництво : Закон України від 07.02.1991. URL: https://zakon.rada.gov.ua/ lawes / show/698-12.

3. Господарський кодекс України : Закон України від 16.01.2003. URL: https:// zakon.rada.gov.ua/laws/show/436-15.

4. Про державну реєстрацію юридичних осіб, фізичних осіб-підприємиів та громадських формувань: Закон України від 15.05.2003. URL: https: / / zakon.rada.gov.ual laws / show/755-15.

5. Про розвиток та державну підтримку малого $i$ середнього підприємництва в Україні : Закон України від 22.03.2012. URL: https://zakon.rada.gov.ua/laws/ show / 4618-17.

6. Цивільне право України. Загальна частина: підручник / за ред. О.В. Дзери, H.C. Кузнєцової, Р.А. Майданика. Київ : Юрінком Iнтер, 2017. 976 c. 